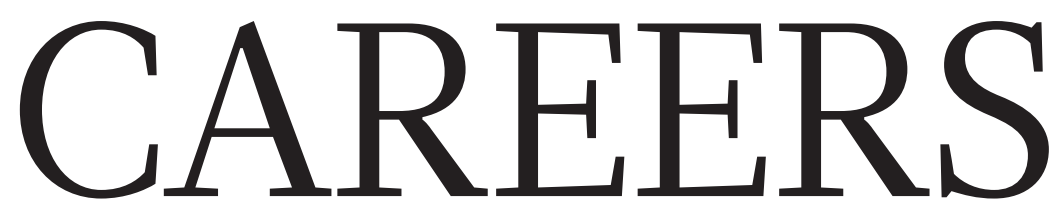

PANORAMIC VISION Conservation, satellite imagery and women in science $\mathbf{p . 4 6 5}$
NETWORKING Build your own scientific community go.nature.com/62k75f
NATUREJOBS For the latest career

listings and advice www.naturejobs.com

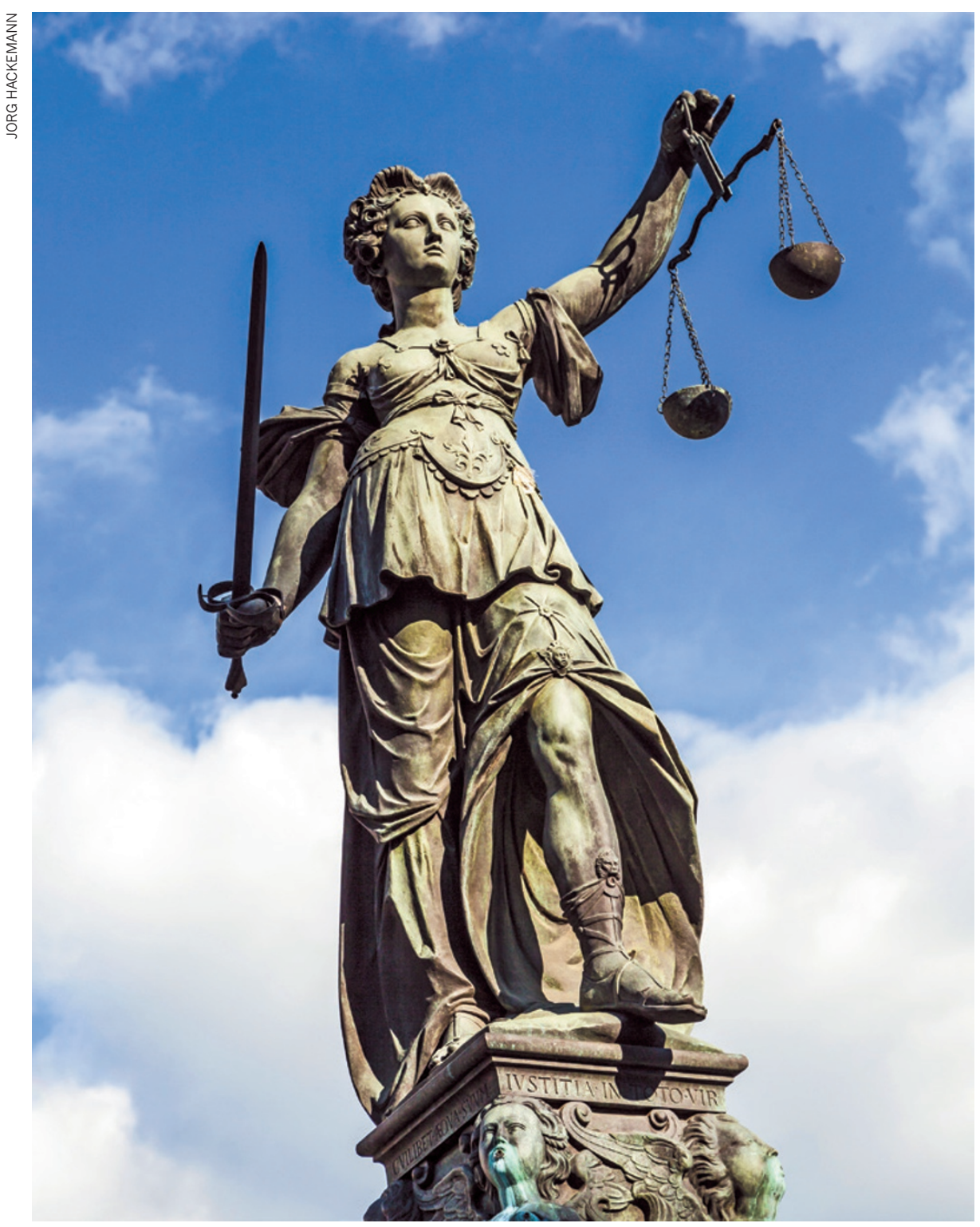

Lady Justice stands as a symbol of a court system that often calls on witnesses to ensure fair trial.

SCIENCE IN COURT

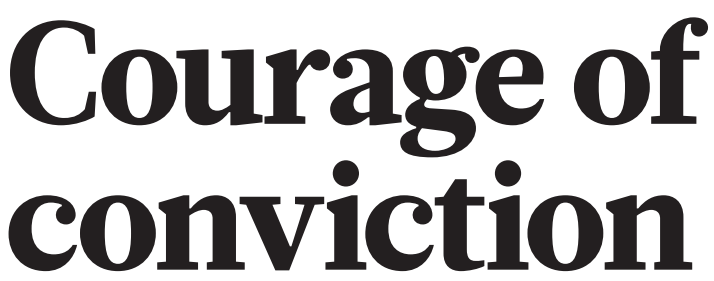

Expert witnesses have a crucial role in bringing science into the legal system - but the job is not without pressure.
BY VIRGINIA GEWIN

Tn October 2006, Bradley Waldroup attacked his estranged wife with a machete and shot her friend to death. In the subsequent trial, his defence attorney argued that Waldroup had a genetic variant that has been linked to aggression. As a result, the defence argued, he was less able to control his behaviour than are people who do not have the variant.

Charged with first-degree murder of the friend and attempted first-degree murder of his wife, Waldroup was convicted in 2009 of voluntary manslaughter and attempted seconddegree murder, and received a 32-year sentence. Had he been found guilty of the more-serious charges, he would have faced the death penalty. Waldroup's defence was bolstered by the testimony of forensic psychiatrist William Bernet of Vanderbilt University in Nashville, Tennessee, and forensic neuropsychologist James Walker, who together performed a full psychological review of the defendant. Bernet identified that Waldroup carried a genetic variant that, when coupled with his abusive childhood, potentially increased the risk of violent behaviour. Waldroup also had another genetic variant that seems to raise the risk for depression, Bernet said. News stories at the time quoted some jurors as saying that the genetic evidence helped to persuade them that Waldroup could not fully control his actions.

The jury's verdict outraged many in the US legal and scientific communities, who argued that a genetic variant was being used to absolve Waldroup of responsibility for his crimes. Extrapolating from population studies to a single man and a single gene variant was scientifically unsound, says Judith Edersheim, a lawyer-turned-psychiatrist at Harvard Medical School in Boston, Massachusetts. In 2008, she and her colleague Bruce Price created the Center for Law, Brain and Behavior at Massachusetts General Hospital in Boston to help to improve how scientific findings are used in legal settings.

As a result of rapid technical advancements, neuroscience and other scientific disciplines are poised to bring more researchers into courtrooms. That presents scientists with an opportunity for well-compensated public service, but it can be a double-edged sword. The demands of the courtroom can be exasperating and sometimes even threaten professional reputations.

Taking on the role of expert witness tends to be time consuming, and it is often combative and stressful. It can prove crucial in judicial decisions, but deciding to step into the 
- witness box is not a choice that a researcher should make lightly. "Trial is like sport - you have to be a gamer to be good," Edersheim says.

\section{UNDER FIRE}

Generally, scientists are contacted to serve as expert witnesses on the basis of their perceived expertise and whether they will provide an impartial and accurate opinion. But lawyers' assessment of expertise can be surprising. "A scientist's publications, journal impact factors or citation numbers are not necessarily considered a reliable index," says Allen Hirson, a phonetics researcher at City University London who is often called on to identify speakers, decipher indistinct speech or establish whether audio recordings have been tampered with. The scientists most sought after are those who can communicate effectively on the witness stand, and reputations as an expert witness are built largely through word of mouth. "When I do a good job on the stand, my name is passed on to others and my phone starts ringing off the hook," he says. As one of only a handful of people in the United Kingdom with a high level of expertise in such analyses, he is in high demand.

People who are tapped to be expert witnesses do not merely walk up to the stand, recite data and figures and render an opinion on culpability. Many are unfamiliar with the byzantine operations of the legal system and will need to have some form of training. In the United States, attorneys who hire them will typically spend time training them for trial (see 'Courses for would-be expert witnesses').

Andrew Moll, a deputy public defender in San Bernadino County, California, says that

for low-level criminal cases, an expert can expect to spend roughly eight hours preparing to testify and at least four hours on the stand. More-complicated cases may require a lot more than that. Hirson once spent six days being cross-examined in the witness box in a highprofile terrorist case. He spent a couple of weeks before that on an electronic presentation of his evidence to help him to explain what was being said and by whom.

The casework also rarely offers much recognition. Legal reports often require as much work as a manuscript, but they are not published in peer-reviewed journals and so yield no academic accolades, observes Martin Hall, a forensic entomologist at the Natural History Museum in London. Perhaps more troubling for scientists who are new to the legal system is that they can have little data to work with. "Every case is unique, which can be challenging for scientists who like to replicate everything," he says.

Researchers also need a thick skin. "Not only will a scientist's expertise be questioned, so will their integrity," says Michael Saks, who researches legal decision-making at the Center for Law, Science and Innovation at Arizona State University in Tempe. "It can be unpleasant reading reports from colleagues that are worded to make you sound incompetent," agrees David Ozonoff, who was the first chair of the environmental-health department at Boston University's School of Public Health and has served as an expert witness in asbestos cases for 30 years. He warns that researchers can expect to be called 'hired guns' or worse.

Even more discomfiting, say experienced witnesses, is a heated cross-examination. "It

\section{TRAINING}

\section{Courses for would-be expert witnesses}

Programmes in the United Kingdom and the United States train scientists on how best to deliver their scientific expertise in a legal setting - for example, such that they meet court standards for admissibility. In London, the Expert Witness Institute (EWI) provides workshops on topics such as report writing and cross-examination. It also connects lawyers with expert witnesses.

In partnership with University College London's Faculty of Laws, the EWI completed a pilot certification of experts, who were evaluated on their ability to prepare a report on a model case and undergo cross-examination. Teaming up with Cardiff University Law School, a training outfit called Bond Solon offers three five-day expert-witness certifications - for civil, criminal and family cases. In the United States, Harvard Medical School's continuing education programme in Boston offers training for medical professionals who are eager to know how to handle a malpractice claim.

Although training can help experts understand what to expect, some fear that attorney preparation can introduce bias. Itiel Dror, a cognitive neuroscientist at University College London, says that would-be expert witnesses must protect the integrity of their contribution. He advises researchers to insist that lawyers and law-enforcement officials do not provide irrelevant information that could even unintentionally introduce bias to their interpretation of the data.

In the autumn 2015 newsletter, EWI governor Kay Linnell notes that the British judiciary and the European Institute of Expertise and Experts in Versailles, France, look favourably on people taking certification courses so that they learn what is expected of them in legal settings. "It may not be long before we are asked to demonstrate our bona fides," she writes. V.G.

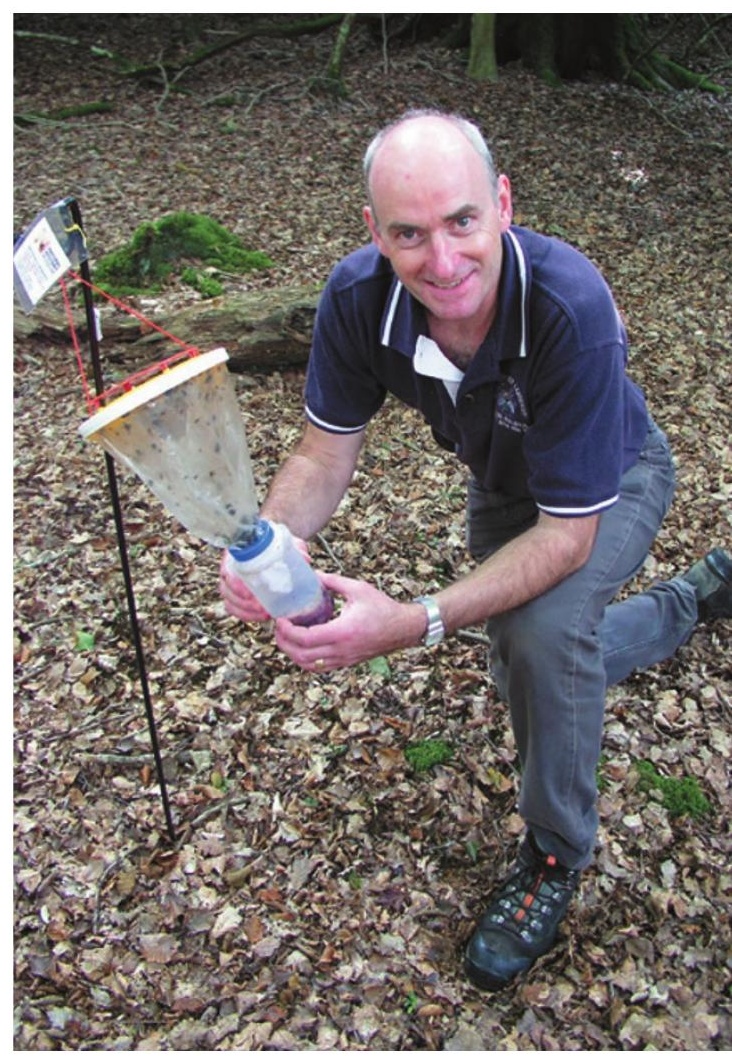

Martin Hall with blowfly trap in the New Forest, UK.

will be uncomfortable; that's the nature of the game," says Mark Chernaik, a staff scientist at the non-profit group Environmental Law Alliance Worldwide in Eugene, Oregon. Chernaik often testifies against well-resourced defendants - such as multibillion-dollar mining companies - who, he says, try to find every embarrassing statement he has ever made and tear apart every word of opposing testimony. "Not everyone's nervous system is built for being on a witness stand," says Chernaik.

Ozonoff says that he enjoyed the work, especially when intellectual sparring was involved, and became known as a good witness. But he has tired of it, mainly because of "depositions that were becoming really nasty". He likens the frosty relations to how US Republicans and Democrats no longer share a drink or work together in Congress. "The same thing happened in litigation," he says.

\section{HIGHER CALLINGS}

The notoriety generated by being on a witness stand underscores how important it is for scientists to remain in their area of expertise, Edersheim points out. "In the age of the Internet, there is no hiding. Everyone - your colleagues, your dean and your lab partner - will know what you said in court." She adds that scientists also often do not realize that whatever they say will be immortalized in a trial transcript, which can come back to haunt them if they contradict themselves in a trial years later.

Yet there are pay-offs, financial and otherwise, to serving as an expert witness. Ozonoff 
estimates that he was deposed 400-500 times, almost always for civil suits that hinged on when the asbestos industry learned about health concerns associated with its products. Although he routinely undercharged clients and sometimes worked pro bono, the income he earned during those 30 years helped to send his children through private school and university.

No one should expect to get wealthy from working as an expert witness. Ozonoff was able to devote time to many cases because his university allowed him to spend one day per week consulting. But some institutions, such as RTI International in Research Triangle Park, North Carolina, stipulate the terms under which an employee can serve as an expert witness; for example, he or she can testify only on research results performed by the institute. Other institutions, including the Natural History Museum in London, allow their employees to spend time on cases, but take the fee to offset the lost hours.

Hall has not benefitted financially from his work as an expert witness, but his experiences have stimulated research ideas. He is often called on to use his knowledge of blowfly development to help police to establish the latest possible time of death. He worked on a case in which bodies were found in suitcases, but he struggled to find research that would help him to determine how long it would have taken insects to find the bodies. So he did the experiments himself and found that it depends on weather: in summer, flies would take a day or two to get to the body; in winter, it could take two weeks. "My MSc student got beautiful video of an ovipositor [an insect's egg-laying organ] pushing through the zippers of a suitcase," he says.

Ultimately, serving in this capacity is about making a contribution to society, researchers say. Ozonoff recalls that only once did a colleague suggest that anyone who testified in court was for sale. "My testimony was true," he says. "And my expertise was being put to good use."

That is the most fundamental reason for a scientist to accept the request, says Owen Jones, director of the MacArthur Foundation Research Network on Law and Neuroscience at Vanderbilt Law School in Nashville, Tennessee. It is an opportunity to make science matter in a broader sphere. "The legal system will never be better informed than when scientists take the time to help it move in a more constructive and accurate direction," he says.

Edersheim views serving as an expert in the courts as both an honour and a duty. "The legal system is the underpinning of democratic society," she says. "If a scientist participates with integrity, it is as high a calling as any other." -

Virginia Gewin is a freelance writer in Portland, Oregon.

TURNING POINT

Nathalie Pettorelli

Nathalie Pettorelli has pioneered the use of satellite imagery to inform conservation policy. The Zoological Society of London ecologist received an award this year from British Prime Minister David Cameron for her guerrilla efforts to promote women in science.

\section{How did you come to use satellite imagery for} conservation?

I was very interested in conservation but found that more data would be available if I focused on wildlife management. For my $\mathrm{PhD}$ at the Laboratory of Biometry and Evolutionary Biology in Lyons, I studied the habitat quality of a roe-deer population in southwest France that is managed by national hunting offices. Two months later, I started a postdoc at the University of Oslo to study the impact of climate on vegetation and deer-population dynamics. It was then that I started to look at satellite data to quantify vegetation productivity. I trained myself in the use of remotesensing data, for example, those collected from aircraft or satellites.

\section{Were they easy to apply to conservation?}

No. Experts told me it would be extremely difficult, if not impossible, to use these tools to study wildlife. I thought the best way was to see for myself. At the time, no one I knew was working with remote sensing: it was taught in geography, not biology. The turning point was when NASA released free satellite data. I wrote a review on the satellite data I wanted to use, and started to meet people in that community. Now I am well connected.

\section{How did you first apply these techniques?}

I did a postdoc at Laval University in Quebec, Canada, using satellite data to monitor dynamics in ungulates. Then a job at the Zoological Society of London took me on several trips to the Serengeti National Park in Tanzania to work on cheetah dynamics. Although that work did not lead to real-world conservation measures, other projects have.

\section{What successes are you most proud of?}

I used satellite data to show that the vegetation dynamics of a game reserve in Chad could sustain a reintroduction of Scimitar-horned oryx (Oryx dammah). I am also proud of my work to highlight how the declining health of mangroves in Bangladesh and India has contributed to erosion of the coastline - of up to 100 metres in 2 years. I have also been working to improve policymakers' use of satellite data to inform decision-making.

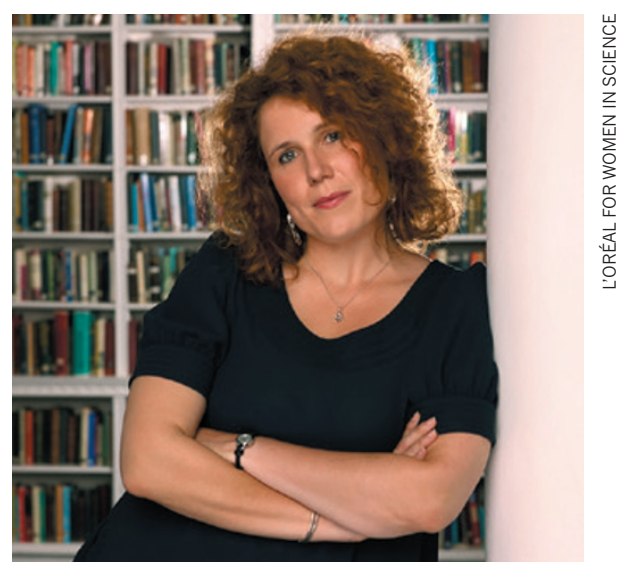

What is Animove?

Together with colleagues, we wanted to train people to work at the interface of biological monitoring and remote sensing. Animove is our programme to build that capacity. We have taught a hands-on course every year since 2013 in North America and Europe, and the goal is to bring it to Africa, Asia and South America.

\section{What is Soapbox Science?}

Seirian Sumner, a behavioural biologist at the University of Bristol, UK, and I founded Soapbox Science in 2011. By then, we had each won a L'Oreal-UNESCO women in science fellowship and were interested in science communication, yet had noticed fewer female colleagues as we progressed in our careers. I found myself working on issues involving hunters, which was not female-friendly. We wanted to change perceptions of what a scientist looks like. We organize events to showcase 12 female scientists who speak about their work in busy areas of cities - such as the South Bank in London or near a tube exit in Newcastle. The women present their work, and the public can heckle or ask questions. We were surprised to get a call from the prime minister's office this year announcing that we had won a Point of Light award for making a change in the community.

\section{Did landing a permanent position make a big difference?}

It took me years to get it. But even before I had job security or a title, I wrote a book, started Soapbox Science and have been pushing at an international level for greater use of satellite imagery. Success is not a one-way road. It's possible to achieve a lot even when a job situation isn't stable.

\section{INTERVIEW BY VIRGINIA GEWIN}

This interview has been edited for length and clarity. 


\section{CORRECTION}

The Careers feature 'Courage of conviction' (Nature 526, 463-465; 2015) gave the wrong date for the conviction of Bradley Waldroup: the verdict was passed in 2009. The article also mischaracterized the part in the defence proceedings played by William Bernet. Bernet - together with James Walker - performed a complete psychiatric and neuropsychological profile of Waldroup and as a result identified that the defendant had a high-risk gene variant that, when coupled with his abusive childhood, could arguably increase his risk of violent behaviour. Bernet did not undertake any of the research linking this genetic variant to antisocial behaviour, as suggested by our article, but only presented a summary of extant scientific knowledge to the jury. Comments in the article also inadvertently could have been read as directly criticizing Bernet's testimony; this was not the intention and the text has now been corrected online to resolve this issue (see go.nature.com/xdi44d). 